\title{
Production Function Estimation with Industry Capacity Data *
}

\author{
Plutarchos Sakellaris
}

\author{
University of Maryland and \\ Board of Governors of the Federal Reserve System
}

August 16, 2000

\begin{abstract}
This paper introduces a new data set for the analysis of productivity in U.S. manufacturing. It consists of data on production and input levels when the plants in an industry operate at capacity. The estimates are consistent with those obtained using data on actual operations from the ASM. As an application, I use this data to estimate the rate of growth of technological change that is embodied in equipment capital. The estimates imply a larger role of equipment investment and embodied technological change on economic growth than is conventionally assumed.

Keywords: productive capacity, capacity utilization, productivity growth, embodied techological change, production function.

JEL codes: D24, E22.

${ }^{*}$ Department of Economics, University of Maryland, College Park, MD 20742 (plutarch@electra.umd.edu). I would like to thank Carol Corrado for many discussions, Norman Morin and Charlie Gilbert for guidance with the data, and Ojas Desai, and Susan Polatz for research assistance. Some of the capacity data used in this paper were collected under the provisions of Title 13 U.S. Code and are only available at the Center for Economic Studies (CES), U.S. Census Bureau. The research in this paper was conducted by the author as a research associate at the CES. The views expressed here do not represent those of the Board of Governors of the Federal Reserve System, its staff, or the U.S. Census Bureau.
\end{abstract}




\section{Introduction}

This paper introduces a new data set for the analysis of productivity in U.S. manufacturing. It consists of data on production and input levels when the plants in an industry operate at capacity. This data originates in the Survey of Plant Capacity (SPC) and is partly used by the Federal Reserve Board to calculate industrial capacity utilization. I demonstrate here that the implementation of econometric production functions using this data leads to results comparable to those obtained with the conventional data on actual operations such as those in the NBER-CES Manufacturing Productivity database that originate mostly in the Annual Survey of Manufactures. An advantage of the dataset used here is that it contains information on capital utilization as captured by its workquarter. Various studies have argued that failure to account for variable capital utilization contaminates measures of technological change. ${ }^{1}$

As an application, I use this data to estimate the rate of growth of technological change that is embodied in equipment capital. The fundamental idea that more recent vintages of capital may embody technological advances that make them "better" than older vintages was introduced by Johansen (1959) and Solow (1960). ${ }^{2}$ An important implication of this idea is that investment is essential in order to reap the benefits from some part of technological progress.

A series of recent papers has explored the importance of embodied technological change for economic growth. Hulten (1992) and Greenwood et al. (1997), among others, calibrate the rate of growth of embodied technological change using producer durable equipment price indexes constructed by Gordon (1990) to reflect improvements in quality. They compare these to official indexes assumed to contain no quality adjustment and arrive at an estimate of about 3 to 3.5 percent per year.

\footnotetext{
${ }^{1}$ The original concern was voiced by Jorgenson and Griliches (1967). More recent contributions are surveyed in Fernald and Basu (1999) and Beaulieu and Mattey (1996).

2 "Better", or equivalently "of higher quality", means displaying higher productivity after adjusting for wear and tear.
} 
The approach in this paper is to estimate directly this rate of growth using an econometric production function framework. In the language of the duality theory of

production, I work with the primal problem without relying on measures of prices. The framework used here has been proposed by Nelson (1964) and the estimates obtained are much higher than the price-base ones indicating an even larger role for embodied technological change than is conventionally accepted.

\section{The Framework}

The production of gross output in an industry is described by the following equation:

$$
Y_{t}=Z_{t} f\left(U_{t} K_{t}, L_{t}, M_{t}\right)
$$

where, $Z_{t}$ is a factor that captures disembodied technological change, $L_{t}$ is labor input, $M_{t}$ is materials input, $K_{t}=K_{t}^{s}+K_{t}^{e}$ is the sum of the capital stock of structures and equipment respectively, and $U_{t}$ is the rate of utilization of capital in production. The capital stocks are the outcome of past investment decisions by industry firms and of depreciation due to use according to the following equations:

$$
K_{t}^{s}=\sum_{i=1}^{\infty}\left(1-d_{t-i}^{s}\right) I_{t-i}^{s},
$$

and

$$
K_{t}^{e}=\sum_{i=1}^{\infty}\left(1-d_{t-i}^{e}\right) I_{t-i}^{e} q_{t-i} .
$$

It is assumed that investment, $I$, becomes productive with a lag of one period, that is, there is "time to build". The index $q$ measures the technical efficiency of different vintages of equipment. Note that in equation (1) I am making the assumption that there is no embodied technological change in structures.

The production function given by (1) is essentially a description of how a mix of inputs, one of them being technology, leads to a certain amount of output being produced. It is conventionally used to describe actual, that is observed, operations 
but it does not have to be limited to such an application. In particular, firms do not usually operate at full capacity but find themselves utilizing only part of their capacity to produce output. ${ }^{3}$ Suppose that firms or plants gave us information on the inputs they would choose if they were to operate at capacity and how much output they would produce as a result (at curent levels of technology). Conceptually, the functional form in (1) should describe operations at capacity as well. Thus, the firms in the industry have the capacity to produce according to the following equation:

$$
Y_{t}^{c}=Z_{t} f\left(U_{t}^{c} K_{t}, L_{t}^{c}, M_{t}^{c}\right)
$$

where $L^{c}$ and $M^{c}$ are the levels of labor and material inputs when capital is utilized at capacity. Note that capital utilization at capacity, $U_{t}^{c}$, may not be equal to one. Capacity utilization is then defined as

$$
c u_{t}=Y_{t} / Y_{t}^{c}
$$

Assuming that the production function is Cobb-Douglas,

$$
f(K, L, M)=K^{\alpha} L^{\beta} M^{\gamma},
$$

then equation (4) becomes:

$$
\log \left(Y_{t}^{c}\right)=\alpha \log \left(U_{t}^{c}\right)+\alpha \log \left(K_{t}\right)+\beta \log \left(L_{t}^{c}\right)+\gamma \log \left(M_{t}^{c}\right)+\log \left(Z_{t}\right)
$$

where

$$
\log \left(K_{t}^{s}\right)=\log \left(\sum_{i=1}^{\infty}\left(1-d_{t-i}^{s}\right) I_{t-1}^{s}\right)
$$

and

$$
\log \left(K_{t}^{e}\right)=\log \left(\sum_{i=1}^{\infty}\left(1-d_{t-i}^{e}\right) I_{t-1}^{e} q_{t-1}\right) .
$$

The first task of this paper is to estimate (7) together with (8) and (9) using data on capacity operations. These estimates are then compared to results from estimating

\footnotetext{
${ }^{3}$ See Corrado and Mattey (1997) for a discussion of various issues surrounding variable capacity utilization as well as a review of related studies.
} 
(1) in logs together with (8) and (9). These two approaches should be equivalent, the main difference being that the two data sets describe different levels of production operations.

\section{The Age of the Capital Stock}

Nelson (1964) restricts embodied technological change to have a constant growth rate and derives a relationship between this rate and the effect of average capital age on productivity. Let $q_{t} / q_{t-1}=(1+\lambda)$, for all $t$. Then, one can show that, approximately,

$$
K_{t}^{e}=\sum_{i=1}^{t}\left(1-d_{t-i}^{e}\right) I_{t-i}^{e} q_{t-i}=B(1+\lambda)^{t} k k_{t}^{e}\left[1+\lambda\left(a_{0}-a_{t}\right)\right]
$$

where $k k_{t}^{e}=\sum_{i=1}^{t}\left(1-d_{t-i}^{e}\right) I_{t-i}^{e}$ denotes the stock of capital equipment unadjusted for quality change, $a_{i}$ is the average age of the equipment stock at time $i$, and $B$ is a constant that depends on $\lambda$ and $a_{0}$.

Substituting from (10) into (7) and approximating $\log \left(1+\lambda\left(a_{0}-a_{t}\right)\right)$ with $\lambda\left(a_{0}-a_{t}\right)$, I obtain

$\log \left(Y_{t}^{c}\right)=\alpha \log \left(U_{t}^{c}\right)+\alpha \log \left(K_{t}^{s}+k k_{t}^{e}\right)+\beta \log \left(L_{t}^{c}\right)+\gamma \log \left(M_{t}^{c}\right)+\beta \lambda\left(a_{0}-a_{t}\right)+\log \left(Z_{t}\right)$,

after suppressing a linear time trend term. According to Nelson's (1964) framework negative effects of average capital stock age on productivity provide evidence of embodiment. Furthermore, the negative of the coefficient on the age term from such regession is equal to the share of capital times the rate of embodied technological change.

\section{Data}

This paper uses data on actual and capacity operations of manufacturing industries at the three-digit SIC level. The data cover the years 1974 to 1988 and are aggregates computed from plant-level data contained in the Survey of Plant Capacity (SPC) and the Annual Survey of Manufactures (ASM). Some regressions use only data from actual operations and those span the years 1958 to 1996. 
The SPC collects data on fourth-quarter production levels and operations on a subsample of plants in the Annual Survey of Manufactures (ASM). From 1974 to 1988 there were three panels in the years 1974-78, 1979-83, and 1984-88. On average, eight to nine thousand plants per year were surveyed for the SPC about actual, preferred, and practical operations. For each of the three panels, there were six to seven thousand plants that provided data for the entire period. The SPC was modified following the 1988 survey and some of the variables used in the analysis here became unavailable.

\section{Capacity Definitions}

The concepts of capacity conveyed to the survey respondents are defined as follows.

Practical Capacity: "The greatest level of output this plant can achieve within the framework of a realistic work pattern, a normal product mix, and the schedule, machinery, and equipment already in place and ready to operate."

Preferred Level of Operations: "An intermediate level of operations between actual operations and practical capacity that you would prefer not to exceed because of costs or other considerations. Implicit in the idea of a preferred level of operations is the theory that there is a preferred level of operations at which profits are maximized. This is a level where marginal revenue equals marginal costs. The preferred level should not exceed practical capacity."

The second definition is the one I use in this paper as it corresponds quite closely to economic concepts of capacity. ${ }^{4}$ Survey responders indicate the level of production, production worker hours, and the workweek of capital both for actual and capacity operations for the fourth quarter of the year. Capacity utilization is defined as the ratio of production levels at actual and capacity operations. Workweek is calculated as hours worked per day times the days worked per week.

\footnotetext{
${ }^{4}$ This is also the definition used by the Federal Reserve Board (FRB) in constructing estimates of capacity utilization. See Corrado and Mattey (1997) for a description of FRB methods and Doyle (1999) for evidence that the "preferred" measure of capacity aligns well with economic concepts of productive capacity that incorporate cost considerations. Practical capacity, on the other hand, seems closer to an engineering notion of capacity best described as "running the machines all out."
} 
The variables for capacity utilization, capital input, and actual workweek are from the FRB. All other data used here is from the NBER-CES Productivity Database (see Bartelsman and Gray, 1996) except for capacity levels of the workweek and production hours, which are available only at the Center for Economic Studies (CES) of the Census Bureau. The procedure I use to construct industry aggregates is described in the Data Appendix. Capacity output is constructed as the ratio of gross output to capacity utilization.

I also use a set of instrumental variables in some estimations. This consists of quarterly innovations to the Federal Funds rate (lagged one year) and a measure of activity in "downstream industries." The last one is available at the 3-digit SIC level and for years 1978 to 1994 only.

\section{Empirical Results}

I present results pooling all industries together. Table 1 contains the results of OLS estimation of a production function. The first two columns use data on capacity operations while the next two use data on actual operations. Two specifications are used: one that allows for variations in the workweek of capital and another one that does not. Regressions include intercept and linear time trend.

The results are roughly consistent across the two data sets. The coefficient on materials seems to be larger than expected, at least judged by the materials' share in output. Controlling for variation in capital utilization has the effect of reducing the coefficient on capital though it does so much more for data on actual operations. A related observation is that the coefficient on the workweek is very close to that on capital with capacity data but insignificant with actual-operations data.

\section{Endogeneity bias}

It is well-known that there may be biases in OLS estimation of production functions, as in Table 1, due to endogeneity. More concretely, the productivity shock, $\log \left(Z_{t}\right)$, 
may be correlated with the level of inputs. To the extent that this shock has limited serial correlation and capital is quasi-fixed the problem is most severe for the labor and materials input. Presently, there is no good fix for this problem.

Griliches and Ringstad (1973) have proposed a procedure to evaluate the robustness of OLS estimates to endogeneity problems. Their suggestion is to constrain the coefficients of labor and materials to their shares in total cost, calculated from available industry data, but allow the coefficent on capital to be estimated. I use this approach in order to detect possible biases. As may be seen in the first column of Table 2, the coefficient on capital does not change very much, which is reassuring. The coefficient on its workweek, however, increases by 50 percent and so does its standard error. Since the results are mixed, I explore instrumental variables as an alternative.

Some researchers have advocated the use of instrumental variables in order to identify the production function coefficients. Hall (1990) and Burnside et al. (1995) proposed various aggregate-level instruments whereas Shea (1993) and Bartelsman et al. (1994) constructed industry-specific instruments. In particular, the Bartelsman et al. (1994) instrument is a weighted average measure of economic activity in "downstream industries" that demand the output of the industry in question as intermediate input.

I consider the following list of variables as potential instruments: the price of oil, defense spending, the political party of the president, quarterly innovations to the Federal Funds rate and downstream demand level. The aggregate-level instruments suffer from very low relevance to the industry-specific input variables. Shocks to the Federal Funds rate seem to be the least offending of these so I utilize them. The downstream demand variable is very relevant, as would be expected, since it is industryspecific. Table 3 shows the first-stage regressions with the instrument set of four quarters of Federal Funds shocks (lagged by a year) and the downstream-demand. The associated $R^{2}$ s and F-statistics are rather low foreshadowing imprecise, and possibly biased, estimates. One may wonder, then, whether "the cure may be worse for the patient than the disease." 
The second and third column of Table 2 confirm this fear with estimates displaying very high standard errors. However, the actual estimates are not very different from those of OLS. ${ }^{5}$ This provides an indication that, perhaps, the OLS estimates are not severely biased.

\section{Embodied Technological Change}

I proceed now to estimating $\lambda$, the rate of embodied technological change. The estimate of $\lambda$, is about 10 percent, obtained by dividing the coefficient on capital age by the coefficient on capital in Table 4. This estimate is much larger than the estimates based on comparisons of price indexes. It implies a larger role of equipment investment and embodied technological change on economic growth than is conventionally assumed. It also implies that the productive capital stock of equipment is currently mismeasured as it does not reflect substantial improvements in quality through investment in new vintages. Clearly, more research would be useful in assessing the robustness of the high $\lambda$ estimate found here with alternative data and specifications. ${ }^{6}$

\section{Conclusions}

Summing up, the concrete lesson from this paper is that data on industrial productive capacity from the SPC is suitable for production function estimation. In fact, the estimates are quite similar to those obtained using data on actual operations from the ASM. This finding is reassuring for users of the Federal Reserve Board's published measures of capacity utilization, based on the same SPC data.

\footnotetext{
${ }^{5}$ Again the worst offender is the coefficient of the workweek.

${ }^{6}$ Sakellaris and Wilson (2000) take a step in that direction. They construct a large data set of plant operations and estimate the growth rate of embodied technological change without resorting to the approximations inherent in Nelson's (1964) approach.
} 


\section{$5 \quad$ References}

Bartelsman, Eric J., Caballero, Ricardo, and Lyons, Richard K. "Customer- and Supplier-Driven Externalities." American Economic Review, September 1994, 84:4, pp. $1075-84$.

Bartelsman, Eric J., and Gray, Wayne. "The NBER Manufacturing Productivity Database." NBER Technical Working Paper 205, October 1996.

Beaulieu, J. Joseph, and Mattey, Joe. "The Workweek of Capital and Capital Utilization in U.S. Manufacturing." Mimeo, Board of Governors of the Federal Reserve System, August 1996.

Burnside, Craig, Eichenbaum, Martin, and Rebelo, Sergio. "Capital Utilization and Returns to Scale." In NBER Macroeconomics Annual 1995 edited by Julio J. Rotemberg and Ben S. Bernanke. Cambridge, Ma: MIT Press, 1995.

Corrado, Carol, and Mattey, Joe. "Capacity Utilization." Journal of Economic Perspectives, Winter 1997, 11:1, pp. 151-167.

Doyle, Maura P. "The 1989 Change in the Definition of Capacity: A Plant Level Perspective." Mimeo, Board of Governors of the Federal Reserve System, January 1999.

Fernald, John, and Basu, Susanto. "Why is Productivity Procyclical? Why Do We Care?" Board of Governors of the Federal Reserve System, IFDP no. 638, June 1999.

Gordon, Robert J. The Measurement of Durable Goods Prices. Chicago: University of Chicago Press, 1990.

Greenwood, Jeremy; Hercowitz, Zvi; and Krussell, Per. "Long-Run Implications of Investment-Specific Technological Change." American Economic Review, June 1997, $87: 3$, pp. $342-362$. 
Greenwood, Jeremy, and Jovanovic, Boyan. "Accounting for Growth." Mimeo, June 1998.

Griliches, Zvi, and Ringstad, V. Economies of Scale and the Form of the Production Function. Amsterdam: North-Holland, 1971.

Hall, Robert E. "Invariance Properties of Solow's Productivity Residual." In Growth, Productivity, Unemployment: Essays to Celebrate Bob Solow's Birthday. Edited by Peter Diamond. Cambridge, Mass: MIT Press, 1990, pp. 71-112.

Hulten, Charles. "Growth Accounting when Technical Change is Embodied in Capital." American Economic Review, September 1992, 82:4, pp. 964-980.

Johansen, Leif. "Substitution versus Fixed Proportion Coefficients in the Theory of Economic Growth." Econometrica, April 1959, 27, no. 2, pp. 157-176.

Jorgenson, Dale W., and Griliches, Zvi. "The Explanation of Productivity Change." Review of Economic Studies, 1967, 34, pp. 249-283.

Nelson, Richard. "Aggregate Production Functions and Medium-Range Growth Projections." American Economic Review, September 1964, 54:5, pp. 575-606.

Sakellaris, Plutarchos, and Wilson, Daniel. "Vintage Capital and Embodied Technological Change: Plant-Level Estimates." Mimeo, University of Maryland, September 2000.

Shea, John. "Do Supply Curves Slope Up?" Quarterly Journal of Economics, 1993, 108:1, pp. 1-32.

Solow, Robert. "Investment and Technocal Progress." In Kenneth Arrow, Samuel Karlin, and Patrick Suppes, eds., Mathematical Methods in the Social Sciences. Stanford, CA: Stanford University Press, 1960, pp. 89-104. 
Table 1. Estimates of Production Function Parameters: U.S. Manufacturing Industries (3-Digit SIC)

\begin{tabular}{|c|c|c|c|c|}
\hline \multirow[t]{2}{*}{ Variables } & \multicolumn{2}{|c|}{ Capacity Operations } & \multicolumn{2}{|c|}{ Actual Operations } \\
\hline & $\mathbf{A}$ & B & $\mathrm{C}$ & D \\
\hline Labor & $\begin{array}{c}0.201 \\
(0.009)\end{array}$ & $\begin{array}{c}0.257 \\
(0.009)\end{array}$ & $\begin{array}{c}0.250 \\
(0.006)\end{array}$ & $\begin{array}{c}0.254 \\
(0.007)\end{array}$ \\
\hline Capital & $\begin{array}{c}0.185 \\
(0.009) \\
\end{array}$ & $\begin{array}{c}0.137 \\
(0.011) \\
\end{array}$ & $\begin{array}{c}0.133 \\
(0.006) \\
\end{array}$ & $\begin{array}{c}0.127 \\
(0.008) \\
\end{array}$ \\
\hline Materials & $\begin{array}{c}0.614 \\
(0.011)\end{array}$ & $\begin{array}{c}0.665 \\
(0.012)\end{array}$ & $\begin{array}{c}0.638 \\
(0.008)\end{array}$ & $\begin{array}{c}0.639 \\
(0.008) \\
\end{array}$ \\
\hline Workweek of Capital & & $\begin{array}{c}0.140 \\
(0.016)\end{array}$ & & $\begin{array}{c}0.016 \\
(0.013) \\
\end{array}$ \\
\hline RMSE & 0.243 & 0.241 & 0.191 & 0.191 \\
\hline \# Observations & \multicolumn{2}{|c|}{1988} & \multicolumn{2}{|c|}{2835} \\
\hline
\end{tabular}

Note: The data used describe productive operations at capacity levels (columns A and B) or observed levels (columns $\mathrm{C}$ and $\mathrm{D}$ ). The estimating equation is (7) in the text. The capacity-operations sample spans years 1974 to 1988 , whereas the actual-operations sample spans years 1958 to 1996.

Table 2. Estimates of Production Function Parameters: U.S. Manufacturing Industries (3-Digit SIC)

\begin{tabular}{|l|c|c|c|}
\hline \multirow{2}{*}{ Variables } & \multicolumn{2}{|c|}{ Restricted Shares } & Unrestricted Shares \\
\cline { 2 - 4 } & OLS & IV & IV \\
\hline Labor & -- & -- & 0.312 \\
& & & $(1.470)$ \\
\hline Capital & 0.169 & 0.187 & 0.130 \\
& $(0.014)$ & $(0.420)$ & $(0.966)$ \\
\hline Materials & -- & -- & 0.526 \\
& & & $(1.346)$ \\
\hline Workweek of Capital & 0.214 & 0.388 & 0.355 \\
& $(0.049)$ & $(1.380)$ & $0.842)$ \\
\hline R-Squared & 0.137 & 0.004 & 0.175 \\
\hline \# Observations & 1988 & 1434 & 1434 \\
\hline
\end{tabular}

Note: The data used describe productive operations at capacity levels. The first two columns restrict the coefficients of labor and materials to their shares in total cost as calculated from available industry data. The instrument set used in IV estimation consists of a constant, trend, four quarterly shocks to the Federal Funds rate (lagged one year) and a measure of "downstream demand" for industry output. The sample for the OLS estimation is 1974 to 1988 , whereas for the IV estimation it is 1978 to 1988. 


\section{Table 3. Instrument Relevance}

\begin{tabular}{|l|c|c|c|}
\hline Endogenous Variable & R-Squared & F-value & P-value \\
\hline Capital Workweek & 0.010 & 2.520 & 0.020 \\
\hline Labor & 0.020 & 4.902 & 0.000 \\
\hline Capital & 0.009 & 2.241 & 0.037 \\
\hline Materials & 0.007 & 1.687 & 0.121 \\
\hline
\end{tabular}

Note: Relevance statistics of instrumental variables obtained by regressing various input variables on the instrument set. The instrument set includes a constant, trend, federal funds shocks (lagged), and a measure of "downstream demand". Input variables are measured at capacity levels of operations.

\section{Table 4. Estimates of Embodied Technological Change:} U.S. Manufacturing Industries (3-Digit SIC)

\begin{tabular}{|l|c|}
\hline Variables & \\
\hline Labor & 0.256 \\
& $(0.009)$ \\
\hline Capital & 0.139 \\
& $(0.011)$ \\
\hline Materials & 0.665 \\
& $(0.012)$ \\
\hline Workweek & 0.153 \\
& $(0.016)$ \\
\hline Average Equipment Age & -0.014 \\
& $(0.005)$ \\
\hline RMSE & 0.236 \\
\hline \# Observations & 1988 \\
\hline
\end{tabular}

Note: OLS estimation of equation (11) in the text. All variables are measured at capacity levels. The sample spans years 1974 to 1988. 


\section{Data Appendix}

This paper uses data at the three-digit SIC level. The data on actual levels of operations span the years 1958-96, whereas the data on capacity levels of operations span the years 1974-88.

\section{Survey of Plant Capacity (SPC)}

The data on capacity levels of operation come from the U.S. Census Bureau's Survey of Plant Capacity (SPC). The SPC collects data on fourth-quarter production levels and operations on a sub-sample of plants in the Annual Survey of Manufactures (ASM). The ASM provides statistics about U.S. manufacturing plants on an annual basis, drawing upon data from a panel of respondents that is selected every five years. About three-quarters of plants in the SPC remain in the sample for an entire ASM panel. From 1974 to 1988, there were three panels in the years 1974-78, 1979-83, and 1984-88. On average, eight to nine thousand plants per year were surveyed for the SPC about actual, preferred, and practical operations (see Table 1). For each of the three panels, there were six to seven thousand plants that provided data for the entire period. The SPC was modified following the 1988 survey to include questions on full production capability instead of preferred and practical operations.

Table 1: Capacity Definitions

\begin{tabular}{|l|l|c|}
\hline Capacity & Definition & Time Period \\
\hline Practical Capacity & $\begin{array}{l}\text { Greatest level of output this plant can achieve within the } \\
\text { framework of a realistic work pattern, a normal product mix, and } \\
\text { the schedule, machinery, and equipment already in place and } \\
\text { ready to operate. }\end{array}$ & $1974-88$ \\
\hline Preferred Level of Operations & $\begin{array}{l}\text { An intermediate level of operations between actual operations } \\
\text { and practical capacity that you would prefer not to exceed } \\
\text { because of costs or other considerations. Implicit in the idea of } \\
\text { a preferred level of operations is the theory that there is a } \\
\text { preferred level of operations at which profits are maximized. } \\
\text { This is a level where marginal revenue equals marginal costs. } \\
\text { The preferred level should not exceed practical capacity. }\end{array}$ & $1974-88$ \\
\hline Full Production Capability & $\begin{array}{l}\text { The maximum level of production that this establishment could } \\
\text { reasonably expect to attain under normal operating conditions. }\end{array}$ & 1989 -present \\
\hline
\end{tabular}

Source: U.S. Census Bureau's Survey of Plant Capacity MQ-C1 Form and Instructions

Table 2: Assumptions Used in Computing Capacity Estimates

\begin{tabular}{|l|c|c|c|}
\hline Assumption & Preferred & Practical & Full \\
\hline $\begin{array}{l}\text { 1) Do not consider overtime pay, availability of labor, materials, utilities, etc. to be } \\
\text { limiting factors. }\end{array}$ & & $\mathrm{x}$ & $\mathrm{x}$ \\
\hline $\begin{array}{l}\text { 2) Assume a product mix that was typical or representative of your production during } \\
\text { the current quarter. If your plant is subject to considerable short-run variation assume } \\
\text { the product mix of the current period. }\end{array}$ & $\mathrm{x}$ & $\mathrm{x}$ & $\mathrm{x}$ \\
\hline $\begin{array}{l}\text { 3a) Assume the number of shifts and hours of plant operation that can be reasonable } \\
\text { attained by your plant in your community. }\end{array}$ & $\mathrm{x}$ & $\mathrm{x}$ & \\
\hline $\begin{array}{l}\text { 3b) Do not assume number of shifts and hours of plant operations under normal } \\
\text { conditions to be higher than that attained by your plant over the last five years. }\end{array}$ & & $\mathrm{x}$ \\
\hline $\begin{array}{l}\text { 4) Consider only the machinery and equipment in place and ready to operate. Do not } \\
\text { consider facilities or that would require extensive reconditioning before they can be } \\
\text { made operable. }\end{array}$ & $\mathrm{x}$ & $\mathrm{x}$ & $\mathrm{x}$ \\
\hline 5) Assume normal downtime, maintenance, repair and cleanup. & $\mathrm{x}$ & $\mathrm{x}$ & $\mathrm{x}$ \\
\hline $\begin{array}{l}\text { 6) Do not assume increased use of production facilities outside the plant in excess of } \\
\text { the proportion that would be normal during the time period covered by this survey. }\end{array}$ & $\mathrm{x}$ & $\mathrm{x}$ & \\
\hline $\begin{array}{l}\text { 7) Assume the availability of labor, materials, utilities, etc., sufficient to utilize the } \\
\text { machinery and equipment that was in place at the end of the year. }\end{array}$ & $\mathrm{x}$ & $\mathrm{x}$ & \\
\hline
\end{tabular}

Source: U.S. Census Bureau's Survey of Plant Capacity MQ-C1 Form and Instructions 


\section{ASM Variables Used:}

The following series are created from the National Bureau of Economic Research (NBER) / Center for Economic Studies (CES) Manufacturing Productivity Database for the years 1958 to 1994 and the Federal Reserve Board's (FRB) ASM data for the years 1995 and 1996: cost of materials, cost of energy, gross output ${ }^{\square}$ number of employees, number of production employees, inventories, new capital investment, payroll, shipments, value added, and wages. Price deflators for shipments, materials, energy, and new capital investment were also taken from the NBER-CES Manufacturing Database.

\section{Capital Input}

The following describes the construction of industry-level capital input. For each year, the industry-level capital expenditures are split among 35 asset categories. This is accomplished with an iterative matrix balancing (RASing) technique that employs the industry-level investment data as column controls and utilizes NIPA data on asset-level capital expenditures as row controls for the 35 asset categories. Data derived from BEA's Capital Flows Tables (CFTs) provide initial asset-by-industry investment shares for the iterative procedure. For each industry, asset-level net capital stocks are created by adjusting for asset-specific physical depreciation as described in Gilbert and Mohr (1996). Industry-level capital input estimates are constructed as a rental price-weighted Tornqvist index of net capital stocks, $\mathrm{q}(\mathrm{i}, \mathrm{t})$, in the 35 asset categories. The rental price is calculated using the following equation:

$\mathrm{p}(\mathrm{i}, \mathrm{t})=\mathrm{q}(\mathrm{i}, \mathrm{t}) *[\mathrm{r}(\mathrm{t})+(\mathrm{d}(\mathrm{i}, \mathrm{t})-\mathrm{f}(\mathrm{i}, \mathrm{t}))] *[(1-\mathrm{u}(\mathrm{t}) \mathrm{z}(\mathrm{i}, \mathrm{t})-\mathrm{k}(\mathrm{i}, \mathrm{t})) /(1-\mathrm{u}(\mathrm{t}))]$

$q(i, t)=$ chain-weighted investment price deflator for asset $i$ in time $t$

$d(i, t)=$ the rate of economic depreciation for asset $i$ in time $t$

$f(i, t)=$ expected real capital gain for asset $i$ in time $t$

$\mathrm{u}(\mathrm{t})=$ corporate income tax

$\mathrm{k}(\mathrm{i}, \mathrm{t})=$ investment tax credit for asset $\mathrm{i}$ in time $\mathrm{t}$

$\mathrm{z}(\mathrm{i}, \mathrm{t})=$ present value of expected tax depreciation

\section{Capacity Output}

Capacity equals gross output/capacity utilization. This paper uses a series that is constructed by overlaying full production capacity utilization rates (post 1988) with preferred utilization rates (pre-1989) and aggregating to the 3digit level using value added. Both are published by the Federal Reserve Board.

\section{Workweek of Capital at Capacity}

Workweek at capacity equals actual workweek (provided by Norman Morin at the FRB) over workweek utilization (constructed from SPC data at the CES). The workweek of capital was available from the SPC for the years 197488 only. Actual workweek is defined as actual hours worked per day times the actual days worked per week. Capacity workweek was defined in a similar manner. Actual and preferred workweek were aggregated to the 4-digit industry level using the following weight for each plant: SPC weight * total employment (ASM) / shift; where shift is an assigned variable based on the reported actual workweek. If actual workweek is less than 58.5 hours then shift equals one; if actual workweek is greater than 58.5 hours and less than 101.5 hours then shift equals two; and if actual workweek is greater than 101.5 hours then shift equals three. The actual and preferred workweek were aggregated to the 3-digit level using value added weights. The ratio of actual to capacity workweek, in other words workweek utilization, was formed at the 3-digit level.

\section{Labor input at Capacity}

Labor input at capacity equals actual labor input (from the NBER-CES Productivity Database) over the labor utilization (constructed from SPC data at the CES). Actual labor input was imputed using the formula: (Productionworker Hours)*(Total Payroll/ Production-worker Payroll). Labor utilization refers to production-worker hours only as this is the only available information in the SPC data. Actual to capacity ratios were formed for production

\footnotetext{
${ }^{1}$ Gross output is constructed by summing the value added series to the cost of materials series.
} 
worker hours at the plant level. This production-worker-hours ratio was aggregated to the 4-digit level using the SPC weight. Actual employment hours (from the NBER-CES Database) were then used as weights to aggregate to the 3-digit level.

\section{Materials Input at Capacity}

The SPC does not contain information on materials use at capacity operations. I made the assumption that materials utilization was equal to labor utilization for each plant-year observation. Materials input at capacity, then, equals actual materials input (from the NBER-CES Productivity Database) over the labor utilization (constructed from SPC data at the CES).

\section{REFERENCES}

Gilbert, C.E. and Mohr, M. F. "Capital Stock Estimates for Manufacturing Industries: Methods and Data," Federal Reserve Board, March 1996. 